\title{
OPTIMASI WAKTU EKSTRAKSI LEMAK DENGAN METODE SOXHLET MENGGUNAKAN PERANGKAT ALAT MIKRO SOXHLET
}

\author{
Pargiyanti ${ }^{1}$ \\ ${ }^{1}$ Laboratorium Kimia dan Biokimia,Departemen Teknologi Pangan dan Hasil Pertanian, \\ Fakultas Teknologi Pertanian, Universitas Gadjah Mada. Email : pargiyanti@ugm.ac.id
}

Submisi : 11 Oktober 2018; Penerimaan : 12 Februari 2019

\begin{abstract}
ABSTRAK
Lemak dan minyak terdapat pada hampir semua jenis bahan pangan dan masingmasing mempunyai jumlah kandungan yang berbeda-beda. Oleh karena itu analisis kadar lemak suatu bahan pangan sangat penting dilakukan untuk menghitung kalori suatu bahan makanan. Penentuan kadar lemak menggunakan metode Soxhlet memerlukan waktu ekstraksi antara 4 sampai 6 jam untuk mencapai 5 - 6 sirkulasi. Pada penelitian ini analisis lemak menggunakan perangkat alat ekstraksi mikro soxhlet sehingga untuk mencapai 1 kali sirkulasi membutuhkan waktu yang lebih pendek. Penelitian ini bertujuan untuk menentukan lama waktu ekstraksi sehingga analisis lemak dapat dilaksanakan dengan efektif dan efisien. Sampel yang dianalisis adalah jagung, kedelai dan wijen dengan variasi waktu ekstraksi selama 0,5; 1; 1,5; dan 2 jam, dibandingkan dengan 4 jam. Hasil menunjukkan bahwa analisa lemak sampel jagung memerlukan waktu selama 1 jam (3,62 $\pm 0,05 \%)$, sampel kedelai memerlukan waktu 1,5 jam (19,40 $\pm 0,11 \%)$ sedangkan untuk sampel wijen memerlukan waktu 2 jam (19,40 $\pm 0,11 \%)$ untuk mendapatkan hasil yang sama dengan lama ekstraksi 4 jam. Lama ekstraksi lemak pada sampel bisa dilakukan selama 2 jam.
\end{abstract}

Kata kunci : lemak, ekstraksi; lama waktu; mikro soxhlet.

\section{PENDAHULUAN}

Lemak dan minyak adalah adalah salah satu kelompok yang termasuk golongan lipida yaitu senyawa organik yang mempunyai satu sifat yang khas yaitu tidak larut dalam air, tetapi larut dalam pelarut organik misalnya seperti ether, benzene, chloroform, dan lain-lain

Lemak dan minyak merupakan sumber energi yang paling efektif dibandingkan dengan protein dan karbohidrat, 1 gram lemak akan menghasilkan 9 kkal sedangkan protein dan karbohidrat hanya menghasilkan kalori kurang lebih 4 kkal saja (Muchtadi, et.al.,1992). Lemak dan minyak juga merupakan zat yang sangat penting untuk menjaga kesehatan tubuh manusia (Hermanto, Muawanah, \& Wardhani, 2010).

Lemak dan minyak terdapat pada hampir semua jenis bahan pangan dan masing-masing mempunyai jumlah kandungan yang berbeda-beda. Oleh karena itu analisis kadar lemak suatu bahan pangan sangat penting dilakukan agar kebutuhan kalori suatu bahan makanan bisa diperhitungkan dengan baik.

Penentuan kandungan lemak menggunakan pelarut, selain lemak komponen-komponen lain seperti fosfolipida, sterol, asam lemak bebas, karotenoid, dan pigmen lain akan ikut terlarut maka kadar lemak disebur lemak kasar ("crude fat"). Cara analisis kadar lemak kasar secara garis besar dibagi menjadi dua yaitu cara kering dan cara basah. Salah satu cara analisis lemak dengan cara kering yaitu menggunakan metode Ekstraksi Soxhlet (Slamet Sudarmadji, Bambang Haryono, 2007).

Penentuan kadar lemak menggunakan metode Soxhlet memerlukan waktu ekstraksi antara 4 sampai 6 jam untuk mencapai 5 - 6 
sirkulasi. Pada penelitian ini analisis lemak menggunakan perangkat alat ekstraksi mikro soxhlet sehingga untuk mencapai 1 kali sirkulasi membutuhkan waktu yang lebih pendek. Mikro soxhlet adalah seperangkat alat ekstraksi soxhlet berukuran kecil dimana volume labunya 25 - $50 \mathrm{ml}$ dan volume ekstraktornya 10-15 ml.

Penelitian ini bertujuan untuk menentukan lama waktu ekstrkasi sehingga analisis lemak dapat dilaksanakan dengan efektif dan efisien

\section{METODE PENELITIAN}

Penelitian ini menggunakan metode Soxhlet dan alat yang alat yang digunakan adalah mikro soxhlet.

Soxhlet adalah suatu metode suatu metode analisis lemak dengan prinsip kerja sebagai berikut. Pada soxhletasi pelarut pengekstrak yang ada dalam labu soxhlet dipanaskan sesuai dengan titik didihnya sehingga menguap. Uap pelarut ini naik melalui pipa pendingin balik sehingga mengembun dan menetes pada bahan yang diekstraksi. Pelarut ini merendam bahan dan jika tingginya sudah melampaui tinggi pipa pengalir pelarut maka ekstrak akan mengalir ke labu soxhlet. Ekstrak yang terkumpul dipanaskan lagi sehingga pelarutnya akan menguap kembali dan lemak akan tertinggal pada labu. Dengan demikian maka terjadi daur ulang pelarut sehingga setiap kali bahan dieksraksi dengan pelarut baru.(Melwita, Fatmawati, \& Oktaviani, 2014)

Untuk mengetahui kadar lemak berbasis bahan kering maka dilakukan analisis kadar air menggunakan metode Oven (Gravimetri)

Analisis kadar lemak dan kadar air dilakukan 3 kali ulangan untuk masing-masing sampel.
Peralatan : timbangan analitik, oven, penjepit, Eksikator, Perangkat alat ekstraksi mikro Soxhlet, waterbath, blender, Thimbel dari kertas sarin, kapas bebas lemak, dan botol timbang.

Bahan- Bahan : Bahan yang digunakan sebagai pelarut adalah Petroleum Benzena, sedangkan sampel yang di uji adalah jagung, kedelai, dan wijen.

\section{Prosedur kerja :}

Ditimbang sebanyak 1-2 g sampel yang telah dihaluskan menggunakan blender dimasukkan ke dalam thimble yang terbuat dari kertas saring ( A gram). Kemudian ditutup bagian atas menggunakan kapas bebas lemak dan ujung thimble dilipat rapat-rapat kemudian dimasukkan ke dalam tabung Mikro Soxhlet. Hubungkan ujung bawah tabung Mikro Soxhlet dengan labu lemak yang sudah dikeringkan dan diketahui bobotnya ( B gram). Kemudian hubungkan bagian atas ekstraktor Mikro Soxhlet dengan pendingin balik yang sudah dirangkai di atas waterbath. Setelah itu dituangkan petroleum benzena kurang lebih 2 kali volume tabung $( \pm 15 \mathrm{ml})$ dan di- alirkan lewat ujung pendingin balik. Ekstraksi dilakukan dengan variasi waktu selama 0,$5 ; 1 ; 1,5$ dan 2 jam. Sebagai pembanding dilakukan juga ekstraksi selama 4 jam. Diambil labu yang sudah berisi ekstrak lemak kemudian dikeringkan ke dalam oven pada suhu $105^{\circ} \mathrm{C}$. Didinginkan dalam eksikator kemudian ditimbang sampai memperoleh bobot konstan ( $\mathrm{C}$ gram) Dihitung kadar lemak dengan rumus :$$
\text { Kadar lemak }=\frac{(C-B)}{A} \times 100 \%
$$
A: bobot sampel (gram)
B: bobot labu lemak dan lemak (gram)
C: bobot labu lemak kosong (gram) 


\section{HASIL DAN PEMBAHASAN} Analisis kadar lemak

Setelah dilakukan penelitian analisis lemak dengan metode soxhlet menggunakan perangkat ekstraksi mikro soxhlet pada sampel jagung, kedelai dan wijen dengan variasi lama waktu ekstraksi selama 0,$5 ; 1 ; 1,5$ dan 2 jam serta sebagai pembanding dilakukan ekstraksi selama 4 jam maka diperoleh hasil seperti yang sajikan dalam Tabel 1

Tabel 1. Hasil Analisis Kadar Lemak Pada Sampel dengan Variasi Waktu

\begin{tabular}{cccccc}
\hline \multirow{2}{*}{ Sampel } & \multicolumn{5}{c}{ Kadar lemak wb (wet basis) dengan lama waktu ekstraksi } \\
\cline { 2 - 6 } & $0,5 \mathrm{jam}$ & $1 \mathrm{jam}$ & $1,5 \mathrm{jam}$ & $2 \mathrm{jam}$ & 4 jam \\
\hline Jagung & $3,36 \pm 0,04 \%$ & $3,62 \pm 0,05 \%$ & $3,59 \pm 0,03 \%$ & $3,62 \pm 0,07 \%$ & $3,68 \pm 0,03 \%$ \\
\hline Kedelai & $17,61 \pm 0,57 \%$ & $18,88 \pm 0,06 \%$ & $19,40 \pm 0,11 \%$ & $19,50 \pm 0,19 \%$ & $19,44 \pm 0,17 \%$ \\
\hline Wijen & $23,03 \pm 0,45 \%$ & $53,42 \pm 0,42 \%$ & $56,24 \pm 0,35 \%$ & $59,69 \pm 0,66 \%$ & $59,47 \pm 0,42 \%$ \\
\hline
\end{tabular}

\section{Analisis kadar air}

Hasil analisis kadar air disajikan dalam Tabel 2.

Tabel 2. Kadar Air pada Sampel

\begin{tabular}{cc}
\hline Sampel & Kadar air $(\%)$ \\
\hline Jagung & $12,39( \pm 0,05)$ \\
\hline Kedelai & $9,35( \pm 0,05)$ \\
\hline Wijen & $3,28( \pm 0,05)$ \\
\hline
\end{tabular}

\section{Pembahasan}

Hasil analisis lemak sampel jagung dengan lama waktu ekstraksi 4 jam yang tersaji dalam Tabel 1. adalah $3,68 \pm 0,03 \%$, pada pada lama waktu ekstraksi 0,5 jam adalah $3,36 \pm 0,04 \%$. Berdasarkan hasil tersebut, ekstraksi lemak untuk sampel jagung belum bisa selesai dalam waktu 0,5 jam. Pada waktu ekstraksi $1 ; 1,5$ dan 2 jam hasilnya berturut-turut adalah 3,62 $\pm 0,05 \%, 3,59 \pm 0,03 \%, 3,62 \pm 0,07 \%$. Hasil ekstraksi sampel jagung selama 2 jam adalah $3,62 \pm 0,07 \%$ hampir sama dengan hasil ekstraksi 4 jam yaitu 3,68 $\pm 0,03 \%$, hal ini menunjukkan bahwa ekstraksi soxhlet untuk sampel jagung dapat kita hentikan pada jam ke 2 . Berdasarkan data hasil pengamatan kadar lemak dengan metode soxhlet menggunakan perangkat alat mikro soxhlet dengan lama waktu ekstraksi maksimal (4 jam) diperoleh hasil pada sampel jagung sebesar $3,68 \pm 0,03 \%$ sedangkan menurut (Widaningrum, 2010). Persyaratan mutu jagung sebagai bahan baku pakan menurut SNI 01 . 4483-1998 minimal 3\%. Jagung mengandung lemak dan protein yang kadarnya tergantung pada umur dan varietasnya (Husain dkk, 2006).

Pada sampel kedelai dengan lama waktu ekstraksi 4 jam adalah $19,44 \pm 0,17 \%$. Pada lama waktu ekstraksi 0,5 dan 1 jam hasilnya $17,61 \pm 0,57 \%$ dan $18,88 \pm 0,06 \%$. Hasil ini berbeda nyata sehingga bisa dikatakan pada lama waktu tersebut eksraksi belum selesai. Pada lama waktu ekstraksi 1,5 dan 2 jam hasilnya adalah $19,40 \pm 0,11 \%$ dan $19,50 \pm 0,19 \%$. Hasil ini tidak berbeda nyata dengan lama ekstraksi 4 jam sehingga waktu ekstraksi bisa dihentikan selama 1,5 jam. Kemudian pada sampel kedelai diperoleh hasil $19,44 \pm 0,17 \%$. Sedangkan menurut (Isa, 2011) Kedelai merupakan sumber bahan pangan nabati yang mengandung kurang lebih $35 \%$ protein, $35 \%$ karbohidrat dan 18 $20 \%$ lemak serta kandungan gizi lainnya.

Sedangkan pada sampel wijen dengan lama waktu ekstraksi 4 jam hasilnya adalah $59,47 \pm 0,42 \%$. Hasil pada lama waktu ekstraksi 0,$5 ; 1$ dan 1,5 jam berturut-turut adalah 
$23,03 \pm 0,45 \% ; \quad 53,42 \pm 0,42 \% \quad$ dan $56,24 \pm 0,35 \%$. Pada lama waktu tersebut ekstraksi belum selesai karena hasilnya masih berbeda nyata. Tetapi pada lama waktu ekstraksi 2 jam hasilnya adalah $59,69 \pm 0,66 \%$. Hasil ini tidak berbeda nyata dengan hasil ekstraksi sampel wijen yaitu $59,47 \pm 0,42 \%$, sehingga ekstraksi bisa dilakukan selama 2 jam. Pada sampel wijen diperoleh hasil kadar lemak sebesar $59,47 \pm 0,42 \%$. Menurut pelelitian (Puspitasari S., 2012) kadar lemak wijen lebih dari $50 \%$. Wijen merupakan hasil komoditi perkebunan yang dikatakan berlemak karena memiliki kadar lemak antara 18- $50 \%$ (Romadhona dkk., 2015). Dengan demikian bisa dikatakan bahwa hasil analisa analisis lemak pada penelitian ini sudah sesuai.

\section{KESIMPULAN}

Berdasarkan data hasil penelitian ini bisa disimpulkan sebagai berikut.

a. Hasil ekstraksi sampel jagung selama 1 jam yaitu 3,62 $\pm 0,07 \%$, hasilnya hampir sama dengan hasil ekstraksi 4 jam yaitu 3,68 $\pm 0,03 \%$. Jadi ekstraksi soxhlet untuk sampel jagung dapat kita lakukan selama 2 jam.

b. Hasil ekstraksi sampel kedelai selama 1,5 jam yaitu 19,40 $\pm 0,11 \%$, hasilnya hampir sama dengan hasil ekstraksi 4 jam adalah $19,44 \quad \pm 0,17 \%$. Jadi ekstraksi soxhlet untuk sampel kedelai dapat kita lakukan selama 1,5 jam.

c. Hasil ekstraksi sampel wijen selama 2 jam yaitu 59,69 $\pm 0,66 \%$, hasilnya hampir sama dengan hasil ekstraksi 4 jam adalah 59,47 $\pm 0,42 \%$. Jadi ekstraksi soxhlet untuk sampel kedelai dapat kita lakukan selama 2 jam.

\section{UCAPAN TERIMA KASIH}

Terimakasih disampaikan kepada:

a. Dr. Ir. Muhammaad Nur Cahyanto, M.Sc selaku Ketua Departemen Teknologi Pangan dan Hasil Pertanian Dr. Ir. Muhammaad Nur Cahyanto, M.Sc dan dukunganya

b. Kepala Laboratorium Kimia dan Biokimia atas fasilitas yang disediakan

c. Prof. Dr. Ir. Sri Raharjo sebagai pembimbing penulisan Karya Ilmiah ini

d. Dr. Widiastuti Setianingsih, STP. M. SC slaku pendamping dan pembimbing penulisan Karya Ilmiah ini

e. Kepada teman-teman sejawat PLP dan Teknisi Departemen Teknologi Pangan dan Hasil Pertanian atas kerjasamanya

\section{DAFTAR PUSTAKA}

Handajani, S., Manuhara, G. J., \& Anandito, R. B. K. (2010). Pengaruh suhu ekstraksi terhadap karakteristik fisik, kimia dan sensoris minyak wijen. Agritech, 30(2), 116-122.

Hermanto, S., Muawanah, A., \& Wardhani, P. (2010). Analisis tingkat kerusakan lemak nabati dan lemak hewani akibat proses pemanasan. Jurnal Kimia Valensi, 1(6), 262-268.

Husain, H., T. Muchtadi, Sugijono, dan B. Harjanto, 2006. Pengaruh metode pembekuan dan pengeringan terhadap karakteristik grits jagung Instan. Jurnal Teknologi Dan Dan Industri Pangan, XVII.

Isa, I. (2011). Penetapan Asam Lemak Linoleat dan Linolenat pada Minyak Kedelai secara Kromatografi Gas. Saintek, 6 (1980), 1-6. 
M. Yusuf Thoha, Arfan Nazhri S, N., \& Jurusan. (2004). PENGARUH SUHU, WAKTU DAN KONSENTRASI PELARUT PADA EKSTRAKSI MINYAK KACANG KEDELAI SEBAGAI PENYEDIA VITAMIN E.

Melwita, E., Fatmawati, \& Oktaviani, S. (2014). Ekstraksi Minyak Biji Kapuk dengan Metode Ekstraksi Soxhlet. Jurnal Teknik Kimia, 20 ( 192), 20-27.

Puspitasari S. (2012). Minyak Wijen. IImu Gizi FK Undip.

Romadhona, S., Lutfi, M., \& Yulianingsih, R. (2015). Studi Metode dan Lama Pemanasan pada Ekstraksi Minyak Biji Wijen (
Sesamum indicum L ). Jurnal Bioproses Komoditas Tropis, 3(1), 50-57.

Slamet Sudarmadji, Bambang Haryono, S. (2007). Analisa Bahan Makanan dan Pertanian. Liberty Yogyakarta bekerjasama dengan Pusat Antar Universitas Pangan dan Gizi Universitas Gadjah Mada.

Widaningrum, M. dan A. S. S. (2010). PERUBAHAN SIFAT FISIKOKIMIA BIJI JAGUNG ( Zea mays $L$.) PADA PENYIMPANAN DENGAN PERLAKUAN KARBONDIOKSIDA ( $\left.\mathrm{CO}_{2}\right)$. Agritech, 30(1), 1-10. 
LAMPIRAN
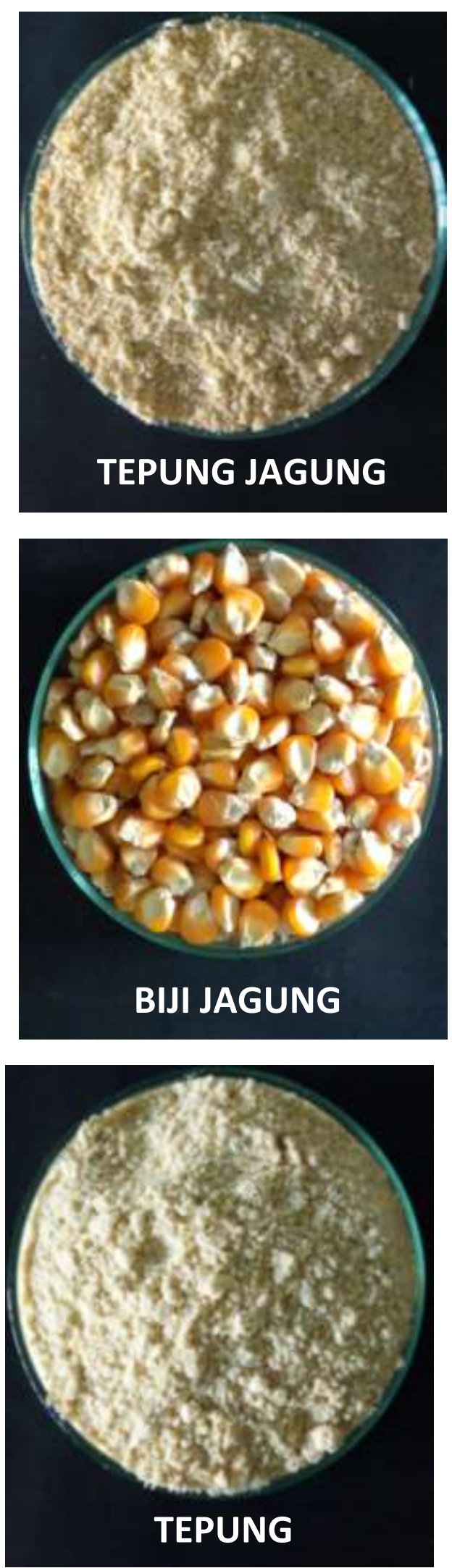
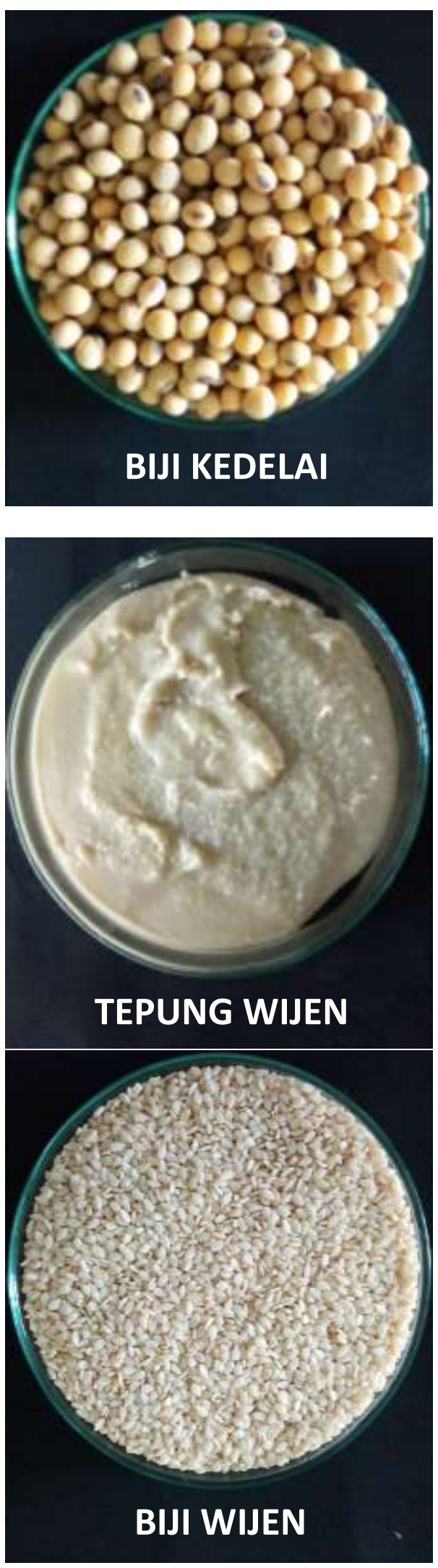

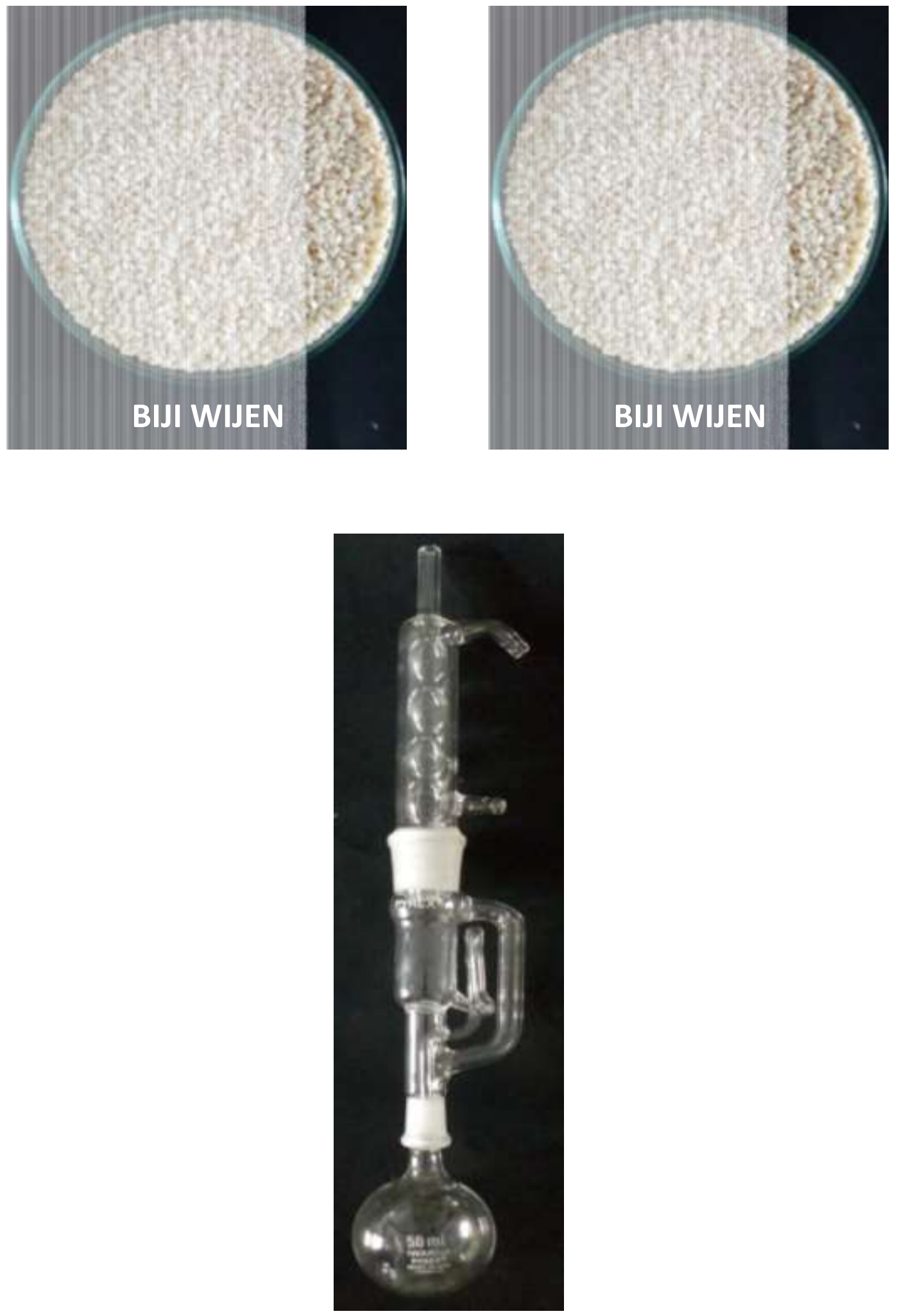

Seperangkat alat ekstraksi mikro soxhlet 